
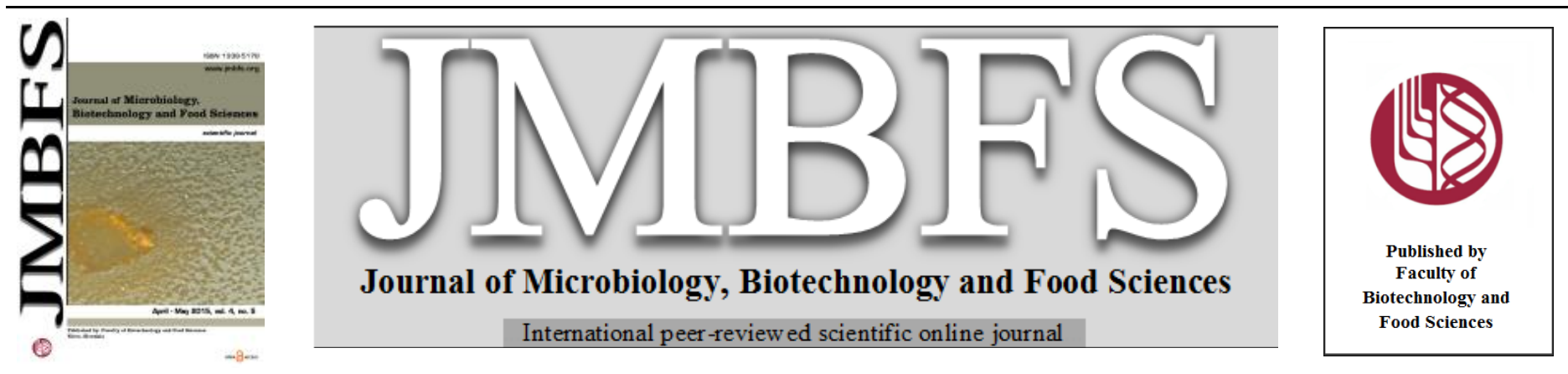

\title{
ANTI-INFLAMMATORY AND CYTOTOXICITY EFFECTS OF SALVADORA PERSICA (MESWAK) EXTRACTS ON JURKAT T-CELLS
}

\author{
Farimah Sardari $^{*}{ }^{1}$,Mohammad Kazemi Arababadi ${ }^{2}$, Marjan Heiranizade ${ }^{l}$, Maryam Mosadeghi $^{l}$
}

Address(es): Dr Farimah Sardari (D.M.D),

${ }^{1}$ Department of Oral Medicine, School of Dentistry, Rafsanjan University of Medical Sciences, Rafsanjan, Iran.

${ }^{2}$ Immunology of Infectious Diseases Research Center, Rafsanjan University of Medical Sciences, Rafsanjan, Iran.

*Corresponding author: drsardari_farimah@yahoo.com

doi: $10.15414 / j m b f s .2015 .4 .5 .379-382$

\section{ARTICLE INFO}

Received 3. 11. 2014

Revised 20. 12. 2014

Accepted 16. 1. 2015

Published 1. 4. 2015

Regular article

OPEN $\partial_{\text {ACCESS }}$

\begin{abstract}
Salvadora persica (S. persica), Meswak, is an evergreen shrub to 6-7 m. It has many biological activities such as antipyretic, antiinflammatory and antifungal activities. This study evaluated in vitro cytotoxic and anti-inflammatory effects of $S$. persica extracts on human oral Jurkat (T leukemia cells). Extracts from Meswak stick and leaves were tested in different concentrations for their cytotoxic and anti-inflammatory activities on human oral Jurkat T- cells. So treated cells viability with increasing concentrations of $S$. persica stick extract $(0.008-0.2 \mu \mathrm{g} / \mathrm{ml})$ and leaves extract $(0.016-0.5 \mu \mathrm{g} / \mathrm{ml})$ for 24,48 or 72 hours was assessed by using the mitochondrial dependent reduction of yellow MTT (3-[4, 5-dimethylthiazol-2-yl]-2, 5-diphenyl tetrazolium bromide) to purple formazan. Also Enzyme-linked immunosorbent assay (ELISA) was performed on supernatants from treated Jurkat T-cells with phytohemagglutinin (PHA) and both extracts to quantify IL-6, IL-8 pro-inflammatory cytokines. Statistically significant differences were indicated by $\mathrm{p}$ $<0.05$. Incubation of Jurkat cells with sterile distilled water, negative control, didn't show any mortality through the incubation period. Against PHA, positive control, both stick and leaves extracts of $S$. persica like resulted in a dose-dependent decrease of IL- 6 and IL- 8 secretion $(\mathrm{p}<0.01)$. Although both extracts significantly inhibited survival of Jurkat cells $(\mathrm{p}<0.01)$ in a dose- and time-dependent manner, stick extract exerted more cytotoxic effects on Jurkat cells than leaves extract of $S$. persica $(\mathrm{p}<0.03)$. In conclusion, although with increasing concentrations of both extracts anti-inflammatory properties were boosted, $S$. persica extracts had dose-dependent cytotoxic effects on human oral Jurkat T-cells.
\end{abstract}

Keywords: Salvadora persica, Jurkat T- cells, cytotoxicity, anti-inflammatory, MTT assay, ELISA

\section{INTRODUCTION}

Salvadora persica (Meswak) is a plant of arid and dry regions such as Saudi Arabia, Iran, North-West India and Africa. Fruits have a sweet, agreeable, aromatic, slightly pungent and peppery taste. Branches and roots of plant widely are used as a stick to clean teeth in Islamic countries (Kumar et al., 2012) Dental plaque is the primary cause of oral disease and dental caries. Therefore, Meswak is necessary to reduce or eliminate it (Al-Bayaty et al., 2010). So that in addition to strengthening the gums for having vitamin $\mathrm{C}$ and betasitoserol, Meswak prevents tooth decay, eliminating toothaches and halt further increase in decay that has already set in. It creates a fragrance in the mouth, eliminates bad odor, improves the sense of taste, and causes the teeth to glow and shine (Hilal and Nizar, 2012). Gamma monoclinic sulfur and benzyl isothiocyanate of plant have anti-bacterial and anti-viral effects (Gazi et al., 1992). Recent studies showed the crude extract of the stick has the inhibitory effect on Bacteriodes gingivalis grow (Alali et al., 2005, Kamat et al., 2011). Also the efficacy of natural toothbrush or miswak in the prevention of dental caries has been investigated and compared with the efficacy of ordinary toothbrush and toothpaste. The results showed that the risk of dental caries for each tooth in the control group was 9.35 times more than the case group (Ezoddini, 2007).

For this reason, recently, the World Health Organization (WHO) is recommended uses the sticks as an effective tool for oral hygiene (Sukkarwalla et al., 2013).

In diseases course, cytokines are the main regulators of the immune response. They induce the balance between inflammatory versus regulatory or antibody mediated reactions (Elenkov and Chrousos, 1999). So, modulating the release of cytokines or inducing them by immunomodulating agents such as S. persica is an attractive mode for treating or help in treating several diseases such as infections. One of the pro-inflammatory cytokines is IL-8. IL-8 is produced by macrophages, fibroblasts and epithelial cells (Kim et al., 2006). This cytokine is believed to play role in inflammation; pathogenesis of inflammatory airway diseases (Hasan and Ibrahim, 2013).
On the other hand, IL-6 that is produced by T-cells, macrophages, endothelial cells (Heikkilä et al., 2008) has both pro-inflammatory and anti-inflammatory properties depending on the inflammatory stimuli, cells that produce it, or the signaling pathway activated (Sultani et al., 2012). Investigations show that $S$. persica extract can decrease the serum level of them (Ibrahim et al., 2011b).

Therefore, According to chemical components of S. persica and dental health important, this study aimed to investigate the anti-inflammatory and cytotoxicity effects of S. Persica aqueous extract on Lymphocyte Jurkat cell line.

\section{MATERIAL AND METHODS}

\section{Plant}

Salvadora persica L. (Salvadoraceae) (Voucher Number: TMRC940) was collected in April 2014 from Bandar Abbas, one province in south of Iran. It was identified and verified by Department of Plant Protection, College of Agriculture, Vali-e-Asr University, Rafsanjan, in south center of Iran.

\section{Extraction}

The fresh S. persica sticks were cut into small pieces and It's leaves and stick were dried in the oven (Venticell, Germany) at $40{ }^{\circ} \mathrm{C}$ before they were homogenized using an electric grinder to obtain a fine powder. Then the powder $(15 \mathrm{~g})$ was macerated in $100 \mathrm{ml}$ of distillation sterile water at room temperature for 48 hours and was maintained at $4{ }^{\circ} \mathrm{C}$. Then mixture was centrifuged for ten minutes with $2200 \mathrm{rpm}$. The obtained supernatant was sterilized by using Millipore filters (pore size 0.2 micro liters) (Sigma-Aldrich, Germany) and was stored in $-20{ }^{\circ} \mathrm{C}$ for next tests. 


\section{Cell line}

Jurkat cells (provided from the Pasteur Institute, Tehran, Iran) were cultured in suspension using Roswell Park Memorial Institute 1640 (RPMI 1640) medium supplemented with $10 \%$ fetal calf serum, $1 \%$ penicillin, $1 \%$ streptomycin and incubated at $37{ }^{\circ} \mathrm{C}$ with $5 \% \mathrm{Co}_{2}$. Cells were resuspended in RPMI 1640 in 72 hour intervals for 21 days. Then cells were collected while in the log phase of growth by centrifugation at $1500 \mathrm{rpm}$ for 10 minutes, and the pellet was resuspended in RPMI 1640 complete growth medium at a concentration of $6 \times$ $10^{3}$ cells $/ \mathrm{ml}$.

On the one hand, for assaying cytotoxicity effect of extracts, cells were divided into four groups with the same condition. First group, negative control, and the second group, positive control, were treated with sterile distilled water and 100 $\mu \mathrm{g} / \mathrm{ml}$ Annona cherimolia extract (cytotoxic natural agent) respectively. Next groups of Jurkat cells $\left(6 \times 10^{3}\right.$ cells $\left./ \mathrm{ml}\right)$ were cultured with different concentrations of $S$. persica leaves and sticks extracts for 24,48 or 72 hours. On the other hand for evaluating anti-inflammatory activity of extracts, cells were divided into 3 groups with similar condition. First group was treated with phytohemagglutinin (PHA), positive control, $(1,2,5 \mu \mathrm{g} / \mathrm{ml})$ and subsequent groups were incubated with extracts of S. Persica for 6, 12, or 24 hours.

Finally in order to assess cytotoxicity effects of extracts and cytokines level (IL-6 and IL-8) in the groups, ELISA and MTT methods were used.

\section{Cytotoxic assay}

The MTT assay was performed to evaluate the cytotoxicity of the selected plant extracts. The cells were seeded in 96-well plates at $6 \times 10^{3}$ for Jurkat in each well. Following $24 \mathrm{~h}$ incubation, the cells were treated with different concentrations (the maximum concentration was $0.2 \mu \mathrm{g} / \mathrm{mL}$ and $0.5 \mathrm{mg} / \mathrm{mL}$ for stick and leaves extract respectively) for $72 \mathrm{~h}$. 3-(4,5-dimethylthiazol-2-yl)-2,5 diphenyl tetrazolium bromide solution, (MTT) solution, $(5 \mathrm{mg} / \mathrm{mL}$ of final concentration) was added to each well and they were incubated at $37{ }^{\circ} \mathrm{C}$ for $4 \mathrm{~h}$ Then the supernatant was removed and the resultant formazan crystals were dissolved in DMSO. The amount of produced formazan is directly proportional to the number of living cells. The absorbance was measured using a microplate reader at $570 \mathrm{~nm}$. Tamoxifen was used as the positive control in the present study.

\section{Cytokines assays}

Measurements of IL- 6 and IL- 8 on culture supernatants were accomplished by ELISA developed using the adapted procedures recommended by the manufacturer (eBioscience, Madrid, Spain). Optical densities were measured at $450 \mathrm{~nm}$ in an automatic ELISA reader (Bio-Tec Instruments Inc., Winooski, VT)

\section{Statistical Analysis}

Data were indicated as mean \pm standard deviation (SD). The independent twosample was used for comparison between groups and $\mathrm{P}$-value $<0.05$ was considered significant. Dose-response curves between cell viability percentages and extract concentrations were constructed.

\section{RESULTS}

\section{Viability assay of Jurkat cells}

We examined the viability of Jurkat cells treated with increasing concentrations of leaves and stick extracts from $S$. persica for 24,48 or 72 hours by using the MTS assay.

The extract significantly inhibited the growth of Jurkat cells $(\mathrm{p}<0.01)$ in a doseand time-dependent manner, especially when treated for 48 and 72 hours. Cell proliferation consistently decreased, and only $21.84 \%$ to $29.00 \%$ of the cells survived after 72 hours of incubation. Using an extract concentration of 500 $\mu \mathrm{g} / \mathrm{ml}$, the minimum inhibitory effect was observed after 24 hours, and the maximum inhibitory effect was observed after 72 hours of incubation.

Therefore, this finding revealed that the Jurkat cells were highly sensitive to the extract after 48 and 72 hours of exposure. The cytotoxic effect may be due to the cytotoxic compounds present in the aqueous extract of $S$. persica such as ursolic acid.

In this study, although both extract had high cytotoxicity effects, the results of cell viability assays showed that stick extract significantly more than leaves extracts $(\mathrm{p}<0.01)$ killed Jurkat cells in a time- and dose-dependent manner. The $\mathrm{IC}_{50}$ for stick and leave extracts was 53.4 and $51.2 \mu \mathrm{g} / \mathrm{ml}$ respectively. The MTT assay results for obtained extract of S. persica leaves and stick were summarized in Tables 1 and 2 .

Table 1 The levels of cytotoxicity of S. persica leave extract

\begin{tabular}{lccccccccccc}
\hline $\begin{array}{l}\text { Leaves extract } \\
\text { Concentration }(\mathrm{mg} / \mathrm{ml})\end{array}$ & $\mathbf{0 . 0 1 6}$ & $\mathbf{0 . 0 3}$ & $\mathbf{0 . 0 5}$ & $\mathbf{0 . 0 6}$ & $\mathbf{0 . 1 0}$ & $\mathbf{0 . 1 6}$ & $\mathbf{0 . 2 5}$ & $\mathbf{0 . 3 3}$ & $\mathbf{0 . 4}$ & $\mathbf{0 . 5}$ \\
& & & & & & & & & & \\
\hline Viability of Jurkat cell & 0.268 & 0.235 & 0.212 & 0.206 & 0.199 & 0.193 & 0.188 & 0.181 & 0.178 & 0.168 \\
\hline
\end{tabular}

Table 2 The levels of cytotoxicity of $S$. persica stick extract

\begin{tabular}{|c|c|c|c|c|c|c|c|c|c|c|}
\hline $\begin{array}{l}\text { Stick extract } \\
\text { Concentration }(\mathrm{mg} / \mathrm{ml})\end{array}$ & 0.008 & 0.015 & 0.025 & $\mathbf{0 . 0 3}$ & 0.05 & 0.08 & 0.125 & 0.165 & 0.20 & 0.25 \\
\hline Viability of Jurkat cell & 0.201 & 0.199 & 0.195 & 0.185 & 0.172 & 0.170 & 0.162 & 0.153 & 0.151 & 0.142 \\
\hline
\end{tabular}

\section{Analysis of anti-inflammatory activity}

Jurkat cells were treated with phytohemagglutinin (PHA) $(1,2,5 \mu \mathrm{g} / \mathrm{ml})$, positive control, and extracts of $S$. Persica for 6,12 , or 24 hours. The secretion of IL-6 and IL- 8 were not altered by the treatment of PHA and both extracts for 6 hours.
Against both extracts, treatment with PHA at $2 \mu \mathrm{g} / \mathrm{ml}$ for 12 hours increased both interleukins secretion from Jurkat cells. In contrast with PHA, incubation of Jurkat cells with leave and stick extracts at $1,2,5 \mu \mathrm{g} / \mathrm{ml}$ for 24 hours resulted in a dose-dependent decrease of IL-6 and IL-8 secretion ( $p<0.01$ ) (Table 3 ). 
Table 3 Serum levels of interleukin-6 (IL-6) and IL-8 in in different concentrations of plant extracts and PHA in different times

\begin{tabular}{|c|c|c|c|c|c|c|c|c|c|}
\hline \multirow[b]{4}{*}{ IL-6 } & \multicolumn{9}{|c|}{ Stick extract } \\
\hline & \multicolumn{3}{|c|}{$1 \mu \mathrm{g} / \mathrm{ml}$} & \multicolumn{3}{|c|}{$2 \mu \mathrm{g} / \mathrm{ml}$} & \multicolumn{3}{|c|}{$5 \mu \mathrm{g} / \mathrm{ml}$} \\
\hline & $6 \mathrm{~h}$ & $12 \mathrm{~h}$ & $24 \mathrm{~h}$ & $6 \mathrm{~h}$ & $12 \mathrm{~h}$ & $24 \mathrm{~h}$ & $6 \mathrm{~h}$ & $12 \mathrm{~h}$ & $24 \mathrm{~h}$ \\
\hline & 2.1 & 4.5 & 3.9 & 2.3 & 4.7 & 3.8 & 2.4 & 4.7 & 2.6 \\
\hline IL-8 & 5.7 & 6.1 & 4.1 & 5.7 & 6.3 & 3.8 & 5.8 & 6.3 & 3.0 \\
\hline & \multicolumn{9}{|c|}{ Leave extract } \\
\hline IL-6 & 2.4 & 3.7 & 3.6 & 2.3 & 4.0 & 2.9 & 2.5 & 3.9 & 2.0 \\
\hline \multirow[t]{2}{*}{ IL-8 } & 5.9 & 6.2 & 5.1 & 5.8 & 6.1 & 4.0 & 5.9 & 6.2 & 3.2 \\
\hline & \multicolumn{9}{|c|}{ PHA } \\
\hline IL-6 & 2.9 & 5.4 & 5.7 & 3.1 & 5.7 & 6.1 & 3.3 & 5.7 & 6.8 \\
\hline IL-8 & 6.2 & 6.5 & 6.5 & 6.4 & 6.8 & 7.1 & 6.5 & 6.9 & 7.5 \\
\hline
\end{tabular}

\section{DISCUSSION}

Drug discovery from medicinal plants has played an important role in the treatment of oral disease and, indeed, most new clinical applications of plant secondary metabolites and their derivatives over the second half of the present century have been applied toward combating infectious diseases (Upadhyay $\boldsymbol{e t}$ al., 2014).

A number of naturally derived agents have been entered into clinical trials after various preclinical trials. The discovery of novel anti-inflammatory agents from natural sources was largely based on the testing for cytotoxic activity against various cell lines grown such as $S$. persica in vitro models (Ibrahim et al., 2011a).

Hence in this study, $S$. persica extracts were isolated and screened for thei cytotoxicity activity against human jurkat cell line. No mortality was observed with negative control containing cell lines, sterile distilled water, which refers to viability of cell lines through the incubation period which meaning that experimental condition without $S$. persica extract didn't hamper the cell cycle. Interestingly, our preliminary study suggested that the aqueous extract of $S$ persica extract produced cytotoxic effects on Jurkat cells at higher doses of concentrations. These inhibitory effects at high doses of extracts may indicate that the cells have the ability to enter the recovery phase at a certain state Furthermore, the extracts of stem and leave of $S$. persica were reported to possess anti-inflammatory activity.

More recently tests have proved the importance role of $S$. persica extracts in some diseases (Sher et al., 2011, Cite and Almas, 2013, Ahmad and Rajagopal, 2013). So that the effects of mouth rinses containing chlorhexidine (CHX) and $S$. persica mouth rinses on periodontal status of patients undergoing fixed orthodontic were compared by Poosti et al. (2007). Gingival index had a significant reduction in all groups after prescribing mouth rinses but this reduction was not significant between groups. Mean pocket depth in $\mathrm{CHX}$ group and gingival bleeding index in $S$. persica group had significant reduction. Plaque index did not show significant reduction in any of the groups (Pousti et al. 2007). Other study is evaluated the extract of root and branches of $S$. persica for analgesic activity in mice. It was found that the drug possesses a relatively moderate analgesic effect which might be due to interaction with the central and/or peripheral opiate system (Mansour et al., 1999).

Also some researchers have described anti-inflammatory and cytotoxicity activities of plant extract on the various cellular lines. So that Ibrahim $\boldsymbol{e t}$ al (2011b) showed the weak activity of Meswak crude extract against different cell lines, but based on the results of present study stick extract showed more cytotoxic activity than leaves extract against tested human jurkat cell line. This finding may be related to various constituents resulting in different biological activities

The results of other study showed both $S$. persica and CHX mouthwashes were toxic to macrophage, epithelial, fibroblast, and osteoblast cells in a concentrationdependent manner (Rajabalian et al., 2009).

Furthermore results of our study implied that both extracts of $S$. persica inhibit PHA-induced IL-6 and IL-8 secretion by Jurkat cells which is in accordance with the results of Ibrahim et al. (2011b). Similarly, Ezmirly et al. (1979) reported anti-inflammatory activity of $S$. persica stem extract.

\section{CONCLUSION}

In conclusion, this is only a preliminary study to demonstrate the antiinflammatory effect of S. persica extracts on Jurkat T cells and further research is necessary to elucidate the detailed mechanism. Furthermore, various in vivo or genetic approaches should be conducted to verify the inhibitory effect of $\mathrm{S}$. persica extract on IL-6 and IL-8 production.

Acknowledgement: We thank to vice chancellor for research in Rafsanjan University of Medical sciences.

\section{REFERENCES}

AHMAD, H., RAJAGOPAL, K. 2013. Biological Activities of Salvadora persica L.(Meswak). Medicinal \& Aromatic Plants, 2, 25. http://dx.doi.org/10.4172/2167-0412.1000129.

AL-BAYATY, F.H., AI-KOUBAISI, A.H., ALI, N.A.W., ABDULLA, M.A 2010. Effect of mouth wash extracted from Salvadora persica (Miswak) on dental plaque formation: A clinical trial. Journal of Medicinal Plants Research, 4, 1446-1454. http://dx.doi.org/10.1109/cssr.2010.5773761.

ALALI, F., HUDAIB, M., ABURJAI, T., KHAIRALLAH, K., AL-HADIDI, N. 2005. GC-MS analysis and antimicrobial activity of the essential oil from the stem of the Jordanian toothbrush tree Salvadora persica. Pharmaceutical biology, 42, 577-580. http://dx.doi.org/10.1080/13880200490901834.

CITE, H., ALMAS, A. 2013. Miswak (Salvadora persica chewing stick) and its role in oral health; an update. Journal of the Pakistan Dental Association, 22 255

ELENKOV, I.J., CHROUSOS, G.P. 1999. Stress hormones, Th1/Th2 patterns, pro/anti-inflammatory cytokines and susceptibility to disease. Trends in Endocrinology \& Metabolism, 10, 359-368. http://dx.doi.org/10.1016/s10432760(99)00188-5

EZMIRLY.S., CHENG, J., WILSON, S. 1979. Saudi Arabian medicinal plants: Salvadora persica. Planta Medica, 35, 191-192. http://dx.doi.org/10.1055/s 0028-1097205.

EZODDINI ARDAKANI, F. 2007. Efficacy of miswak (Salvadora persica) in prevention of dental caries. Health, 2, 495-593. http://dx.doi.org/10.4236/health.2010.25074.

GAZI, M., DAVIES, T.J., AI-BAGIEH, N., COX, S. 1992. The immediate - and medium - term effects of Meswak on the composition of mixed saliva. Journal of clinical periodontology, 19, 113-117. http://dx.doi.org/10.1111/j.1600 051x.1992.tb00449.x.

HASAN, H.A., IBRAHIM, A.I. 2013. Risk factors that are associated with interleukin-8 level in Iraqi asthmatic patients. Asian Journal of Pharmaceutical and Clinical Research, 6, 245-248.

HEIKKILÄ, K., EBRAHIM, S., LAWLOR, D.A. 2008. Systematic review of the association between circulating interleukin-6 (IL-6) and cancer. European journal of cancer, 44, 937-945. http://dx.doi.org/10.1016/j.ejca.2008.02.047.

HILAL, A., NIZAR, A. 2012. Therapeutic properties of meswak chewing sticks: A review. African Journal of Biotechnology, 11, 14850-14857. http://dx.doi.org/10.5897/AJB12.1188.

IBRAHIM, A.Y., EL-GENGAIHI, S.E., MOTAWE, H.M. 2011a. Phytochemical and cytotoxicity investigations of Salvadora persica bark extracts. Journal of The Arab Society for Medical Research, 6, 127-133.

IBRAHIM, A.Y., EL-GENGAIHI, S.E., MOTAWEA, H.M., SLEEM, A.A 2011b. Anti-inflammatory activity of Salvadora persica L. against carrageenan 
induced paw oedema in rat relevant to inflammatory cytokines. Notulae Scientia Biologicae, 3, 22-28.

KAMAT, S., RAJEEV, K., SARAF, P. 2011. Role of herbs in endodontics: An update. Endodontology, 23, 96-100.

KIM, I.B., KIM, D.Y., LEE, S.J., SUN, M.J., LEE, M.S., LI, H., CHO, J.J., PARK, C.S. 2006. Inhibition of IL-8 production by green tea polyphenols in human nasal fibroblasts and a 549 epithelial cells. Biological and Pharmaceutical Bulletin, 29, 1120-1125. http://dx.doi.org/10.1248/bpb.29.1120.

KUMAR, S., RANI, C., MANGAL, M. 2012. A Critical review on Salvadora persica: An important medicinal plant of arid zone. International Journal of Phytomedicine, 4, 292-303.

MANSOUR, M., KHATEEB, T., MAZRAOO, A. 1999. The analgesic effects of Miswak. Saudi Dental Journal, 8, 87-91.

POUSTI, M., RADVAR, M., YAGHOUBI, S., AHMADI, R. 2007. Comparing the effect of Chlorhexidine and Persica mouthrinses on periodontal status of fixed orthodontic patients. Journal of Mashhad Dental School 30, 183-190.

RAJABALIAN, S., MOHAMMADI, M., MOZAFFARI, B. 2009. Cytotoxicity evaluation of Persica mouthwash on cultured human and mouse cell lines in the presence and absence of fetal calf serum. Indian Journal of Dental Research, 20, 169-173. http://dx.doi.org/10.4103/0970-9290.52894.

SHER, H., AL-YEMENI, M.N., WIJAYA, L. 2011. Ethnobotanical and antibacterial potential of Salvadora persica 1: A well known medicinal plant in Arab and Unani system of medicine. Journal of Medicinal Plants Research, 5, 1224-1229.

SUKKARWALLA, A., ALI, S.M., LUNDBERG, P., TANWIR, F. 2013. Efficacy of Miswak on Oral Pathogens. Dental Research Journal, 10, 314 http://dx.doi.org/10.4103/1735-3327.115138.

SULTANI, M., STRINGER, A.M., BOWEN, J.M., GIBSON, R. J. 2012. Antiinflammatory cytokines: important immunoregulatory factors contributing to chemotherapy-induced gastrointestinal mucositis. Chemotherapy Research and Rractice, 2012, 1-11. http://dx.doi.org/10.1155/2012/490804.

UPADHYAY, A., UPADHYAYA, I., KOLLANOOR-JOHNY, A., VENKITANARAYANAN, K. 2014. Combating pathogenic microorganisms using plant-derived antimicrobials: a minireview of the mechanistic basis
research
international,
2014 ,
$1-18$

http://dx.doi.org/10.1155/2014/761741 